\title{
DEVELOPMENT OF SYNBIOTIC WEANING FOOD SUPPLEMENTED WITH SPIRULINA GROWN UNDER PRECISE/MILD STRESS CONDITIONS
}

\author{
Pragya Mishra*1, Sheo Mohan Prasad ${ }^{2}$, Neelam Yadav ${ }^{1}$ \\ ${ }^{1}$ University of Allahabad, Centre of Food Technology, Allahabad, India \\ ${ }^{2}$ University of Allahabad, Department of Botany, Ranjan Plant Physiology and Biochemistry \\ Laboratory, Allahabad, India
}

Corresponding author*
Phone: 9452096368
Email address: 23raksha@gmail.com

\begin{abstract}
For alleviating child malnutrition, functional food from natural resources such as microalgae predominantly cyanobacteria came into existence as consumers today are more health conscious. No work of technological or scientific significance has been reported on standardized method for development of pearl millet weaning food supplemented with Spirulina maxima. Therefore, feasibility trials were done on the basis of sensory attributes analysis. Spirulina powder grown in optimized laboratory conditions was screened for its phytochemical constituents. The standardized product consisted of one part of pearl millet grounded for 5 min cooked with eight parts of water, $5 \%$ salt and $0.8 \%$ of cumin powder. Cooked weaning food mixed with $1 \%$ curd culture, $1.5 \%$ Spirulina powder and incubated for $12 \mathrm{~h}$ (fermentation). Standardized product consisting of this formulation scored $8.13,7.93,7.88,7.94,7.30,8.14$ for colour and appearance, flavour, consistency, mouthfeel, acidity and overall acceptability, respectively on 9 points hedonic scale.
\end{abstract}

Keywords: Spirulina, weaning food, sensory attributes, fermentation, hedonic scale

\section{INTRODUCTION}

Malnutrition, especially due to protein-poor diet is very common in many parts of the world and is emerging as one of the major health problem that is being faced by developing countries of the Asian subcontinent. The problem has caught the attention of policy makers and researchers, as it was well reported that about 870 million people in the world are undernourished in terms of dietary energy supply in 2012 in which about $17.6 \%$ from the South Asian population is undernourished (FAO, 2012). Considering the growth and development of children; weaning is the most important and critical stage. Weaning is the process of expanding the diet to include food and drinks other than breast milk or infant formula as it is the period of infant vulnerability (Sajilata et al., 2008). To be suitable for the feeding of young children, the cereal-based weaning foods are prepared in liquid form by dilution with a large quantity of water, thereby resulting in more volume but with a low energy and low nutrient dense food (Sanni et al., 1999; Egounlety, 2002; Munasinghe et al. 2013). Hence, such products are often poor in nutritional value as they lack essential amino acids such as threonine, lysine and tryptophan (Egounlety, 2002; Munasinghe et al., 2013). Several strategies have been used to improve the nutritive value of weaning foods, namely malting, dry roasting, milling, steaming, boiling, and sprouting 
which are some simple processes being used in the production of weaning foods (Wikramanayaka, 1996; Munasinghe et al., 2013). Milk and cereal (millet)-based complementary foods appear to be unique in the sense that they can deliver a multitude of nutrients to children and complement each other as well. During the last decade, the utilization of microbial sources, particularly microalgae like cyanobacteria as a nonconventional source of food and protein seems promising (Pulz and Gross, 2004; Rodrigues et al. 2015) and has a long history. Knowing their physicochemical characteristics is fundamental for the selection of the most suitable microalgae to specific food technology applications and consequently successful novel foods development (Batista et al., 2013). Of all the blue-green algae, Spirulina (Arthospira) platensis/maxima have received the greatest interest (Kamenidou et al., 2011, Mishra et al. 2015). Spirulina is virtually immune from problems of contamination and indirectly attest to its safety and has been proven safe for human consumption and have numerous health benefits (Ciferri, 1983, Karkos et al. 2010). A combination of probiotics and prebiotics has also been employed to enhance the health benefits of infant formulae referred as synbiotics. The dietary supplement market for probiotics/synbiotic is gaining momentum at a very fast pace over the globe, hence, regulation of these products is a must for consumers safety (Sarkar, 2011).

It has been reported that Spirulina could improve the quality of fermented dairy products via increasing the rate of in vitro development of several strains of microorganisms present in them (Bhowmik et al., 2009) and due to its complex composition it might be used for supplementation in synbiotics formulations (Finamore et al. 2017). Charalampopoulos et al., (2002) developed a functional weaning food using novel cereal components as substrates and developed dietary fibre, prebiotics and probiotics. For commercial purposes, it is especially fruitful and important to isolate or search for strains endowed with more favourable characterristics like faster growth, better biomass yield, higher specific cell constituents, adaptability in stress, etc.

Thus, a systematic screening of two different strains of Spirulina grown under two different mild stress condition i.e. $\mathrm{Zn}^{2+}$ I UV-B radiation was performed to identify the most suitable strains in terms of biomass and phytochemical production.

In India, we have traditional products touted as functional but have little scientific validation. It was envisaged that preparation and standardization of Spirulinasupplemented milk and cereal-based weaning food in combination with fermentation with curd culture for flavour enhancement would offer the potential for the development of a simple and nutritious product with some probiotic efficacy made from locally available underutilized raw materials.

Spirulina can be considered safe in healthy subjects, even though sensory characteristics of a functional food are important as per consumer acceptance of the product (Finamore et al. 2017). It was therefore, planned to carry out feasibility studies on the development of such a product, with sensory attributes forming the basis of the study.

\section{MATERIALS AND METHODS}

\section{Raw materials}

\section{Pearl millet}

Wholesome, insect free, pearl millet (Pennisetum glaucam) grains with an average mass of each kernel $8.9 \mathrm{mg}$ of hybrid variety were procured from local market of Allahabad district, Uttar Pradesh (Fig. 1A).

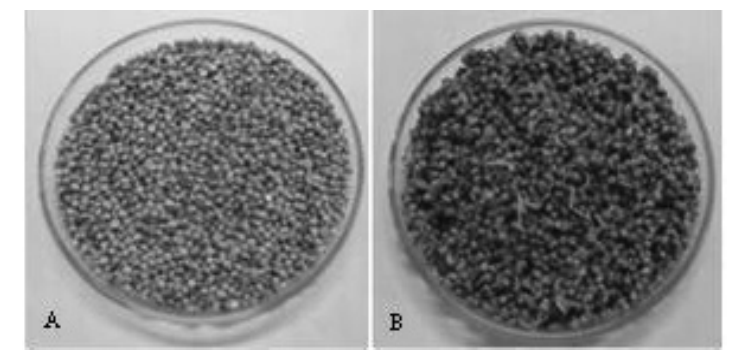

Figure 1. Whole Pearl millet grains $(A)$; Sprouted pearl millet grains (24 h) (B)

The pearl millet grains were germinated 
for $24 \mathrm{~h}$ (Fig. 1B) for removal of antinutritional factor and to increase the digestibility.

\section{Curd culture procurement and preparation of curd}

Mesophilic mixed strain curd culture NCDC-167 (Lactococcus lactis ssp. lactis, Lactococcus lactis ssp. cremoris and Lactococcus lactis ssp. lactis biovar. Diactetylactis in 1:1:1 ratio) was supplied by $\mathrm{Na}$ tional collection of Dairy cultures (NCDC), Dairy microbiology division, National Dairy Research Institute, Karnal, Haryana, India. Curd was prepared by inoculating $1 \%$ of curd culture NCDC-167 in skimmed milk and incubated at $37^{\circ} \mathrm{C}$ for $24 \mathrm{~h}$.

\section{Other ingredient}

Salt, cumin seed powder and skimmed milk were procured from the local market.

\section{Harvesting of Spirulina powder grown in optimized laboratory conditions and maintenance of axenic culture of Spiru- lina maxima}

Pure culture was harvested in liquid broth media under broad spectrum antibiotic (ex. gentamycin) to prevent the growth of other class of bacteria as per our previously set protocol (Mishra and Prasad, 2015). The culture was maintained in Zarrouk's medium (Zarrouk, 1966) at $27 \pm 2{ }^{\circ} \mathrm{C}$ under the photo-synthetically active radiation (PAR) of $75 \mu \mathrm{mol}$ photon $\mathrm{m}^{-2} \mathrm{~s}^{-1}$ with a $16 / 8 \mathrm{~h}$ of light/dark period. The next step in the study was to optimize the growth behaviour of S. maxima in two different stressses i. e. $\mathrm{Zn}^{2+} / U V-B$. The cells were exposed to varying concentration of $\mathrm{Zn}^{2+}$ (i.e. $1.0,1.5,2.0,2.5,3.0,3.5,4.0,4.5,5.0$, $6.0,8.0$ and $10.0 \mathrm{mg} \mathrm{L}^{-1}$ ) and UV-B (i. e. $0.05,0.1,0.2,0.4,0.6$ and $0.8 \mu \mathrm{mol}$ photon $\mathrm{m}^{-2} \mathrm{~s}^{-1}$ for $4 \mathrm{~h}$ daily). On the basis of above preliminary growth experiments, a mild range of $\mathrm{Zn}^{2+}$ stress i.e. 2.5 as stimulatory dose, 3.5 as moderate dose and $4.5 \mathrm{mg} \mathrm{L}^{-1}$ as high dose were selected for exposure of $\mathrm{Zn}^{2+}$ by adding them to the growth medium. Similarly for UV-B stress; 0.05 was selected as stimulatory dose, 0.2 as moderate dose and $0.6 \mu \mathrm{mol}$ photon $\mathrm{m}^{-}$ ${ }^{2} \mathrm{~s}^{-1}$ as high dose and denoted as UV- $B_{1}$, $U V-B_{2}$ and $U V-B_{3}$, respectively for further analysis of physiological and biochemical characteristics of the Spirulina species (unpublished data). S. maxima grown under mild stress of $\mathrm{Zn}^{2+}$ and $U V-\mathrm{B}_{1}$ in Ranjan Plant Physiology and Biochemistry Laboratory was selected for the product development. As the cultures were grown in the liquid medium it was harvested using filter paper and washed with distilled water 3-4 times, then dried in hot air oven at $50{ }^{\circ} \mathrm{C}$ for complete removal of moisture. Then it was preserved in plastic bags and kept in air tight container at -20 ${ }^{\circ} \mathrm{C}$ in a deep freezer.

\section{Preliminary phytochemical screening of Spirulina powder}

The mass cultured cyanobacteria was separated from the medium by centrifugation at $8000 \mathrm{rpm}$ for $10 \mathrm{~min}$ and pellets were dried at $50{ }^{\circ} \mathrm{C}$ for 24 hours. The dried Spirulina sample was ground into a fine powder by using mortar and pestle. Powdered sample was immersed in methanol solvent $(10 \mathrm{ml})$ and placed in a shaking incubator for 24 hours at $25^{\circ} \mathrm{C}$. The solvent extracts were concentrated under reduced pressure at $40{ }^{\circ} \mathrm{C}$ by vacuum evaporator. The concentrated sample used for the presence of phytochemicals such as carbohydrates, steroids, terpenoids, saponins, alkaloids (Sofowora, 1993), amino acids, tannins and flavonoids (Trease and Evans, 2002).

\section{Processing of pearl millet grains}

Soaking: The pearl millet grains were cleaned and washed with water and soaked in water: $0.1 \%$ formaldehyde solution in the ratio of $1: 3$ for $24 \mathrm{~h}$ at room temperature.

Germination: After draining the soaking water, the grains were placed between the folds of muslin cloth drying tray and then the grains were allowed to germinate at room temperature $\left(24-35{ }^{\circ} \mathrm{C}\right)$ for the period of $24 \mathrm{~h}$ (Akubor and Obiegbuna, 1999). Water was sprinkled intermittently to moist the cloth and paper (Khetarpaul and Chauhan, 1989; Narasimha and Malleshi, 2003; Hassen et al., 2006).

Drying: The germinated grains were dried at $55-60{ }^{\circ} \mathrm{C}$ for $8 \mathrm{~h}$ (up to moisture content $5-6 \%)$. The rootlets dried grains were re- 
moved by scrubbing with hands (Abbey and Berezi, 1988).

Dehusking: The germinated and dried grains were coarsely ground in a low speed mixer for $5 \mathrm{~min}$ to remove husk (Hassen et al., 2006).

Cooking: The pearl millet grains were cooked in addition with water, salt and cumin seed powder in a pressure cooker for 1530 min (Ejeta et al., 1987).

Standardization of the method for the development of Spirulina-supplemented milk and cereal-based weaning food

\section{Optimization of particle size of the pearl millet}

The dried pearl millet grains were subjected to grinding at low speed mixer for different time periods: without grinding, 10 and 5 min to prepare 3 samples A, B and $\mathrm{C}$, respectively. All the three samples were soaked in water for half an hour and then cooked in a pressure cooker for $30 \mathrm{~min}$ with $5 \%$ salt, $0.8 \%$ cumin powder and sufficient amount of water. After cooking, the samples were cooled to room temperature and then given to panel of semi trained judges for sensory evaluation.

\section{Optimization of quantity of water to pearl millet ratio}

The dried and dehusked pearl millet grains were cooked as detailed in the previous section using different pearl millet grain to water ratios of 1:6 (B), 1:8 (C) and 1:9 (A). After cooking, the samples were cooled to room temperature and then given to panel of semi trained judges for the sensory evaluation.

\section{Optimization of incubation time for fermentation}

The product was prepared using the pearl millet to water ratio optimized previously. The cooked pearl millet weaning food was cooled to room temperature. It was then mixed with skimmed milk curd prepared previously and kept ready (skimmed milk cultured with curd culture at the rate of $1 \%$ at $\left.40{ }^{\circ} \mathrm{C}\right)($ El Hag et al., 2002; Hassen et al., 2006). The weaning food was then kept in an incubator at $29{ }^{\circ} \mathrm{C}$ for a different time: without fermentation i.e. $0 \mathrm{~h}(\mathrm{C}), 8 \mathrm{~h}$
(B), $12 \mathrm{~h}(\mathrm{D})$, and $14 \mathrm{~h}(\mathrm{~A})$ for the preparation of four samples. After fermentation, the samples were heated in a microwave oven for $1 \mathrm{~min}$ and then given to panel of semi trained judges for the sensory evaluation.

\section{Preparation of Spirulina-supplemented milk and cereal-based weaning food}

The product was prepared using step by step standardized protocol after a number of trials. The cooked pearl millet weaning food was cooled to room temperature. It was then mixed with skimmed milk curd prepared pre-viously and kept ready (skim milk cultured with curd culture at the rate of $1 \%$ at temperature of $30^{\circ} \mathrm{C}$ ). This food was then added with Spirulina powder at the rate of $0.5 \%(C), 1.5 \%(D), 3 \%(A)$ and without addition of Spirulina (B) for the preparation of four samples and kept in incubator at $29{ }^{\circ} \mathrm{C}$ for $12 \mathrm{~h}$ for fermentation. After that the samples were heated in a microwave oven for $1 \mathrm{~min}$ and given to panel of semi trained judges for the sensory evaluation.

\section{Physicochemical analysis (proximate composition)}

The raw material and final product were analyzed for moisture, protein, fat, carbohydrates, ash and crude fibre content by following the standard methods of AOAC (1984). Along with proximate composition, the colour value was also determined by $X$-rite colorimeter that was calibrated using a white reference standard tile, as described by Ranganna et al., (2005).

\section{Evaluation of the probiotic efficacy of developed pearl millet weaning food}

Prior to sensory evaluation Spirulina supplemented pearl millet weaning food was evaluated for its probiotic efficacy after 12 $\mathrm{h}$ incubation at $29{ }^{\circ} \mathrm{C}$. In brief, a loop of weaning food suspension in normal saline was streaked on nutrient blood agar plate, Mueller-Hinton agar plate and MacConkey agar plate at subsequent time interval of incubation.

\section{Sensory evaluation and statistical ana- lysis}

The Spirulina-supplemented and non-supplemented milk and cereal-based weaning food was evaluated for its sensory cha- 
racteristics by a panel of 15 semi trained judges using a 9-point hedonic scale (Stone et al., 1974). Three replicates of each sample from the three trials of each experiment were used for statistical analysis and the values are reported as mean $\pm S D$. Statistical analysis of the present investigation was subjected to the analysis of variance using Duncan's multiple range test (DMRT) at $p<0.05$ significance level using SPSS-16.0 software.

\section{RESULTS AND DISCUSSION}

This study was carried out in two phases to conduct the feasibility trials on Spirulinasupplemented weaning food based on milk-cereal foods. The first phase was concerned with the optimization of the formulation and processing parameters for developing fermented pearl millet weaning food. In the second phase, optimization of Spirulina supplementation in the developed fermented pearl millet weaning food for sensory and nutritional characteristics was carried out. Recent studies on the positive role of low fluence rate of UV-B in Spirulina spp. has been reported and it was found that there was enhancement in biomass production, photosynthetic pigments, non-enzymatic antioxidants, total phenolic contents, and antioxidant potential (Kumar et al., 2016). Similar to the above studies an attempt was made in the present study to adapt the Spirulina species under mild stress condition (2.5 $\mathrm{mg} \mathrm{L}^{-1}$ of $\mathrm{Zn}^{2+}$ or UV-B 1 ) to enhance their chemical constituents. Thereafter such mild stress-adapted $S$. maxima was harvested by filtration to remove growth medium and dried to make powder. This powder was further utilized for supplementation in weaning food for its value addition. Results obtained are presented hereunder.

\section{Quality of raw material}

The chemical composition of pearl millet flour prepared from raw grains of $24 \mathrm{~h}$ sprouted pearl millet flour is shown in Table 1.

The moisture content of raw pearl millet flour ranged from 9.00 to $9.45 \%$ with an average of $9.26 \%$. The fat, protein and ash content varied from 5.85 to $6.70,9.32$ to
9.85 and 1.33 to $1.69 \%$ with average values of $6.16,9.55 \%$ and $1.54 \%$, respecttively. The carbo-hydrate content calculated by difference ranged from 72.86 to $77.00 \%$ with average value of $74.39 \%$. The moisture and fat content of 24 h-germinated pearl millet grain ranged from 9.15 to $9.75 \%$ and 10.29 to $10.68 \%$ with average values of 9.50 and $10.39 \%$, respectively. The protein, ash and carbohydrates had average values of 10.43, 1.63 and $72.71 \%$ with a slight varying range of 10.22 to $10.55,1.52$ to 1.75 and 70.31 to $75.00 \%$, respectively. The results of proxymate composition of pearl millet were in agreement with the report of Hulse et al., (1980) who regarded pearl millet as 'nutracereal' in view of its unique nutritional profile and myriad of phytochemicals such as fat, vitamins and minerals (Ojokoh et al. 2015).

\section{Preliminary phytochemical screening of crude extract of Spirulina maxima}

The results of preliminary phytochemical screening of methanolic extract of $S$. maxima grown in optimized mild stress condition i.e. S. maxima grown in $2.5 \mathrm{mg} \mathrm{L}^{-1}$ of $\mathrm{Zn}^{2+}$ and exposure of UV $\mathrm{B}_{1}$ showed the presence of phytochemicals with positive test for carbohydrates, amino acids, tannins, steroids, terpenoids, flavanoids, phenols, alkaloids, and a negative test for the saponin presence (Table 2).

Clean safety profile of the methanolic extract of $S$. maxima grown under mild stress was suggested as it was found positive for the presence of phytochemicals and negative for the presence of saponins. The lethal dose (LD 50) of Spirulina has not been determined and unlike other cyanobacteria it exempts any kind of cyanotoxins, thus has been regarded as a GRAS product (Generally Recognized as Safe, FDA, Marles, 2011). So, it is clear that the long-term dietary supplementation of Spirulina does not pose any health risk if consumed in moderation (Yang et al., 2011).

\section{Sensory attributes of pearl millet wea- ning food}

Effect of grinding on pearl millet weaning food 
Results showed that there was no significant difference in colour, appearance and flavour score for all type of grain size studied (Fig.2). The study revealed that the weaning food prepared from the pearl millet grain which was ground for 5 min (C) was maximum as for overall acceptability is concerned.

Effect of water quantity on pearl millet weaning food

There was no significant difference in consistency and flavour score for all levels of water studied. The study revealed that the weaning food prepared from the pearl millet grains cooked with water at a ratio of $1: 8$ (C) was found to be most desirable in terms of overall acceptability (Fig. 3).

Effect of addition of curd culture on weaning food as a producer of probiotic activity

Results showed that there was no significant difference in colour and appearance score for all incubation time intervals studied.

The study revealed that the pearl millet weaning food in which curd culture was added and then incubated for $12 \mathrm{~h}$ (D) was found to be optimal for overall acceptability and better than the other three samples (Fig. 4).

Table1.

Proximate chemical composition of raw and 24 h-sprouted pearl millet flour

\begin{tabular}{lcc}
\hline Constituents & $\begin{array}{c}\text { Raw Flour } \\
(\%)\end{array}$ & $\begin{array}{c}\text { Flour of 24 h-sprouted pearl } \\
\text { millet grains (\%) }\end{array}$ \\
\hline Moisture & $9.26(9.00-9.45)$ & $9.50(9.15-9.75)$ \\
Fat & $6.16(5.8-6.7)$ & $10.39(10.29-10.68)$ \\
Protein & $9.55(9.32-9.85)$ & $10.43(10.22-10.55)$ \\
Ash & $1.54(1.33-1.69)$ & $1.63(1.52-1.75)$ \\
Carbohydrate (by difference) & $74.39(72.86-77.0)$ & $72.71(70.31-75.0)$ \\
\hline
\end{tabular}

Table 2.

Preliminary phytochemical screening of methanolic extract of S. maxima

\begin{tabular}{lcc}
\hline Compound & $\begin{array}{c}\text { S. maxima extract } \\
\left(2.5 \text { mg L }^{-1} \text { of } \mathbf{Z n}^{2+}\right)\end{array}$ & $\left.\begin{array}{c}\text { S. maxima extract } \\
(\text { UV B }\end{array}\right)$ \\
\hline Carbohydrates & + & + \\
Amino acids & + & + \\
Tannin & + & + \\
Steroids & + & + \\
Terpenoids & + & + \\
Flavanoids & + & + \\
Saponin & - & - \\
Phenol & + & + \\
Alkaloids & + & + \\
\hline
\end{tabular}

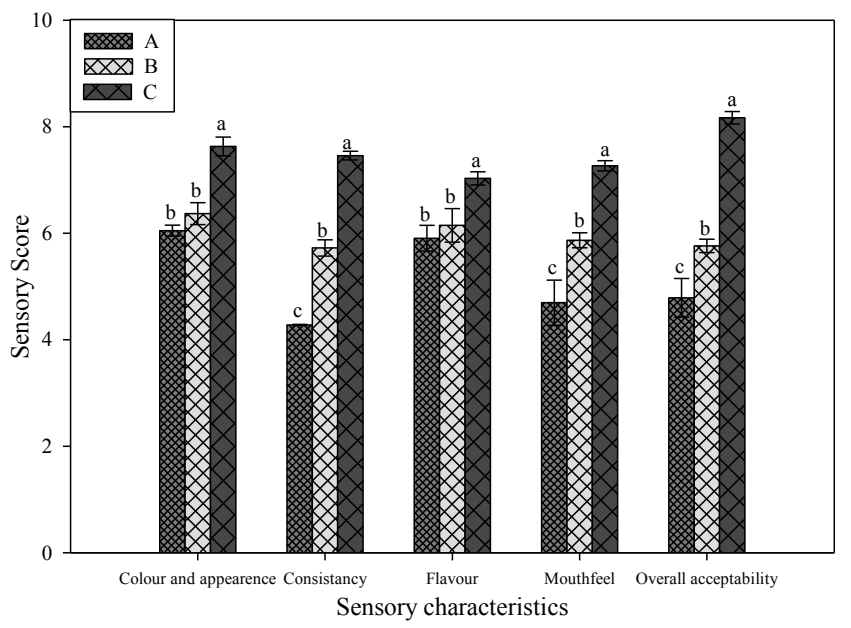

Figure 2. Effect of grinding time on sensory characteristics of pearl millet weaning food. Values are means $( \pm$ SD). Means not sharing a common superscript letter in a column are significantly different at $P<0.05$ as assessed by Duncan's multiple range test. $A=$ without crushing, $B=$ crushing for 10 min and $C=$ crushing for 5 min 


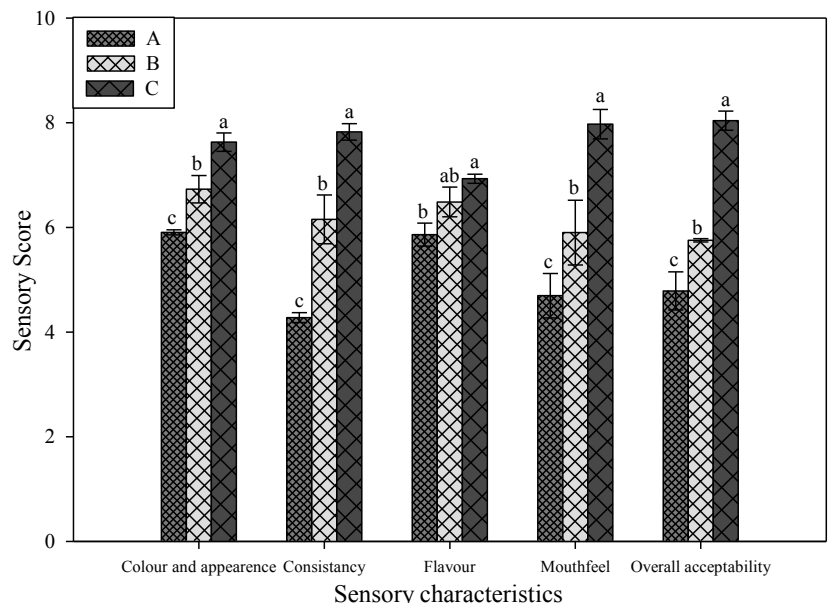

Figure 3. Effect of pearl millet to water ratio on sensory characteristics of pearl millet weaning food. Values are means $( \pm S D)$. Means not sharing a common superscript letter in a column are significantly different at $P 0.05$ as assessed by Duncan's multiple range test. Ratio with water during cooking: $A=1: 9, B=1: 6$ and $C=1: 8$

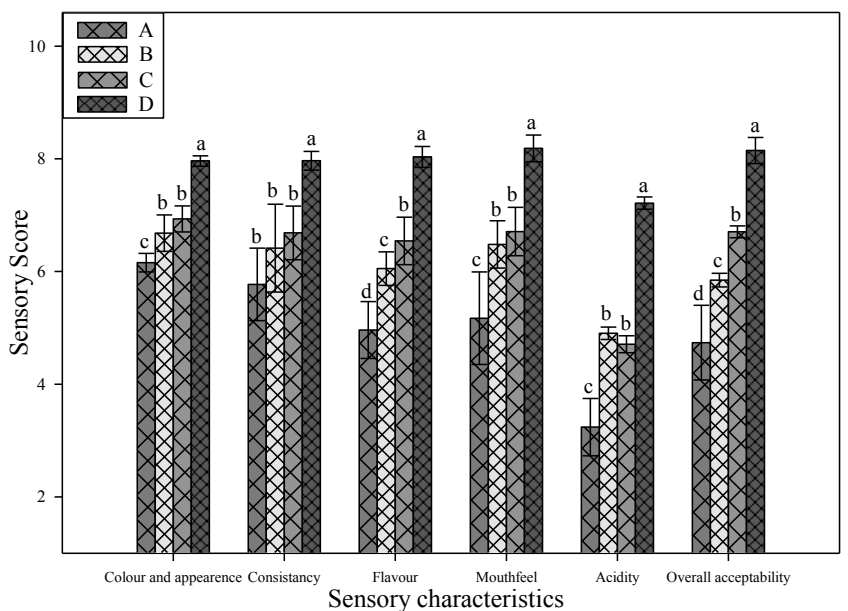

Figure 4. Effect of incubation time on sensory characteristics of milk cereal-based weaning food. Values are means $( \pm \mathrm{SD})$. Means not sharing a common superscript letter in a column are significantly different at $P 0.05$ as assessed by Duncan's multiple range test. $A=14 \mathrm{~h}, \mathrm{~B}=8 \mathrm{~h}, \mathrm{C}=$ without fermentation and $\mathrm{D}=12 \mathrm{~h}$



Figure 6. Effect of supplementation of Spirulina powder on sensory characteristics of milk cereal-based weaning food. Values are means $( \pm S D)$. Means not sharing a common superscript letter in a column are significantly different at $P 0.05$ as assessed by Duncan's multiple range test. $A=3 \%, B=$ without Spirulina, $C=0.5 \%$ and $D=1.5 \%$ 
It was reported that endogenous enzyme phytase of pearl millet contributed significantly to the reduction of the phytate content of fermented pearl millet flour which was dependent on $\mathrm{pH}$ and temperature of fermentation. It was inferred that the fermentation process released unidentified polyphenols and converted phycocyanin to phycocyanobilin (Patel and Goyal, 2013).

Based on the results, it was suggested that fermented Spirulina can be a potent supplement for weaning food due to presence of lactic acid bacteria i.e. Lactococcus lactis, Streptococcusthermophilus, Lactobacillus casei, Lactobacillus acidophilus, and Lactobacillus bulgaricus (Gupta et al. 2017)

Despite numerous beneficial properties of probiotic bacteria, it is also useful to mention their safety and efficacy in formula supplemented with probiotics.

Suitability of probiotics for premature infants or in infants with immune deficiency must be evaluated because of limited data regarding the mechanisms of probiotic action, appropriate administrative regimens, and probiotic interactions (Sarkar, 2011) (Fig 5).

Along with this the total plate count was also found to be more $\left(1.17 \times 10^{9}-\right.$ $\left.1.04 \times 10^{10} \mathrm{CFU} \mathrm{g} \mathrm{g}^{-1} \mathrm{DM}\right)$ in Spirulinasupplemented weaning food than in the non-supplemented food $\left(1.03 \times 10^{9} \mathrm{CFU} \mathrm{g}{ }^{-1}\right.$ DM). As it was previously reported by Bhowmik et al., (2009) that dry algal biomass of Spirulina $\left(10 \mathrm{mg} \mathrm{ml}^{-1}\right)$ stimulates proliferation of probiotic lactic acid bacteria to $86 \%$.

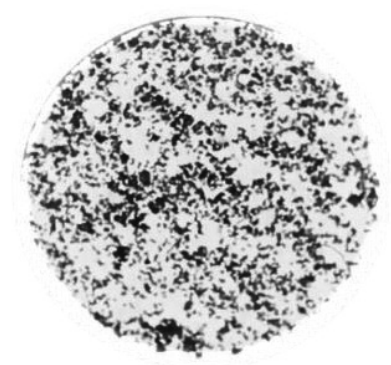

Figure 5. Milk cereal-based weaning food containing Lactococci and Lactobacilli are seen under $100 x$ magnification of oil immerson microscopy Effect of supplementation of Spirulina
powder in pearl millet weaning food

The sprouted and dried pearl millet grains ground for 5 min and then cooked with water ratio of $1: 8$. Prepared pearl millet weaning food was fermented by adding curd culture at the rate of $1 \%$. This food was then added with Spirulina powder at the rate of $0.5 \%(C), 1.5 \%(D)$, and $3 \%$ $(A)$, and without addition of Spirulina (B) for the preparation of four samples and kept in incubator at $29{ }^{\circ} \mathrm{C}$ for $12 \mathrm{~h}$ for fermentation.

The statistical analysis of different sensory score revealed that there was no significant difference in flavour, consistency, mouthfeel and acidity except colour and appearance score which also affected the overall acceptability of the product.

The study revealed that the pearl millet weaning food supplemented with $1.5 \%$ (D) Spirulina powder and then incubated for $12 \mathrm{~h}$ was found to be the best-ranked as far as overall acceptability was concerned and was better than the other three samples (Fig. 6).

To develop milk and cereal-based weaning food supplemented with Spirulina, ingredients such as pearl millet, water, skimmed milk, curd culture, salt, cumin seed and S. maxima powder (grown under mild stress condition) were selected and their quantity in the formulation were standardized in a preliminary trial.

According to PFA (2008), milk and cerealbased complementary foods, commonly referred to as weaning or supplementary foods based on milk (Sabikhi, 2007), cereals and/or legumes (pulses), soybean, millets, nuts and oil-seeds could be processed to low moisture content and then fragmented to permit dilution with water or milk.

As it was reported that the pearl millet (family: Poaceae) ranks sixth most important grain and used in preparation of weaning food by people living in arid land zones (Balten-sperger, 2002). Here, the supplementation of $S$. maxima powder in weaning food was done in combination with fermentation (12 h). 


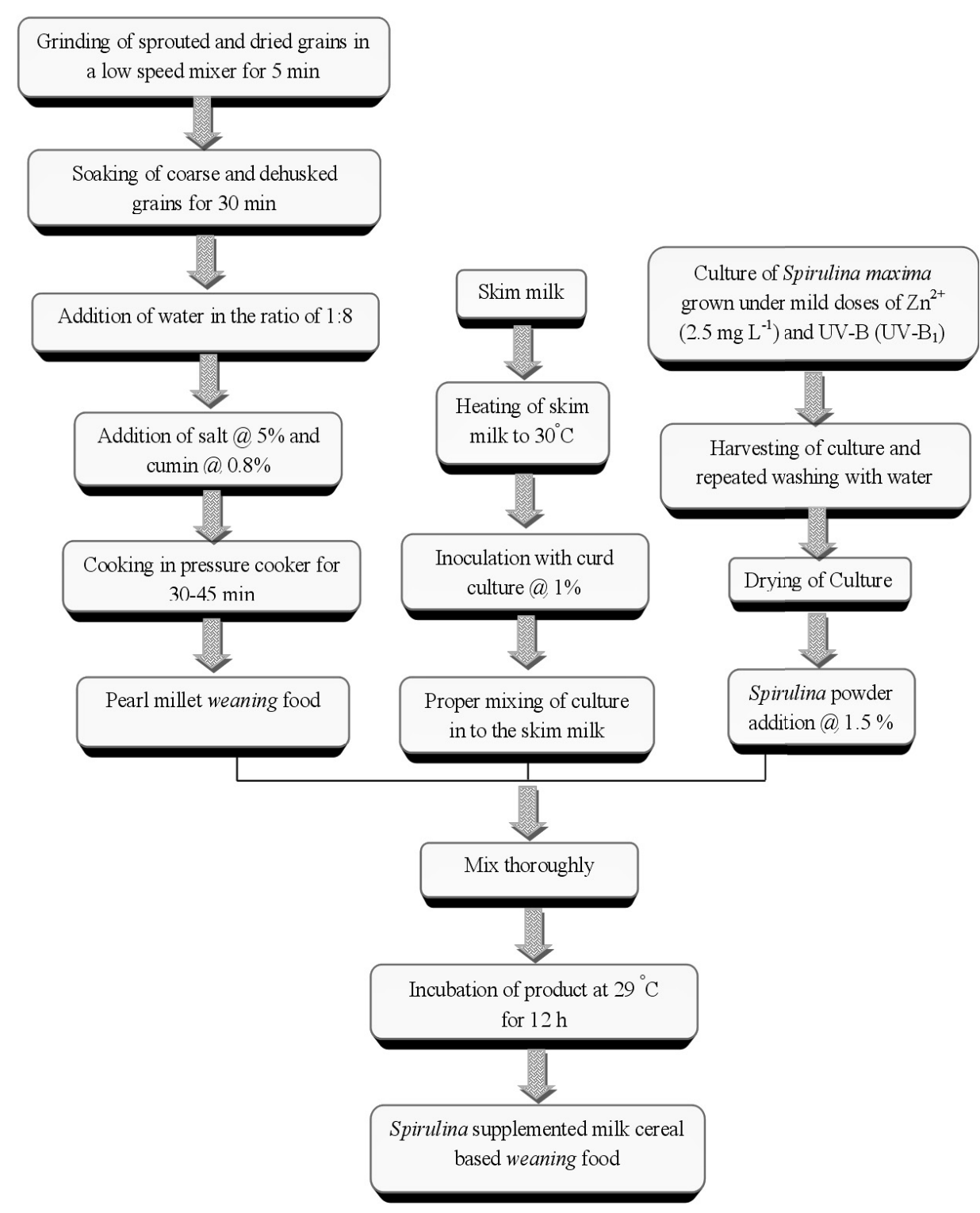

Figure 7. Schematic diagram of the standardized process for the development of Spirulinasupplemented milk and cereal-based weaning food

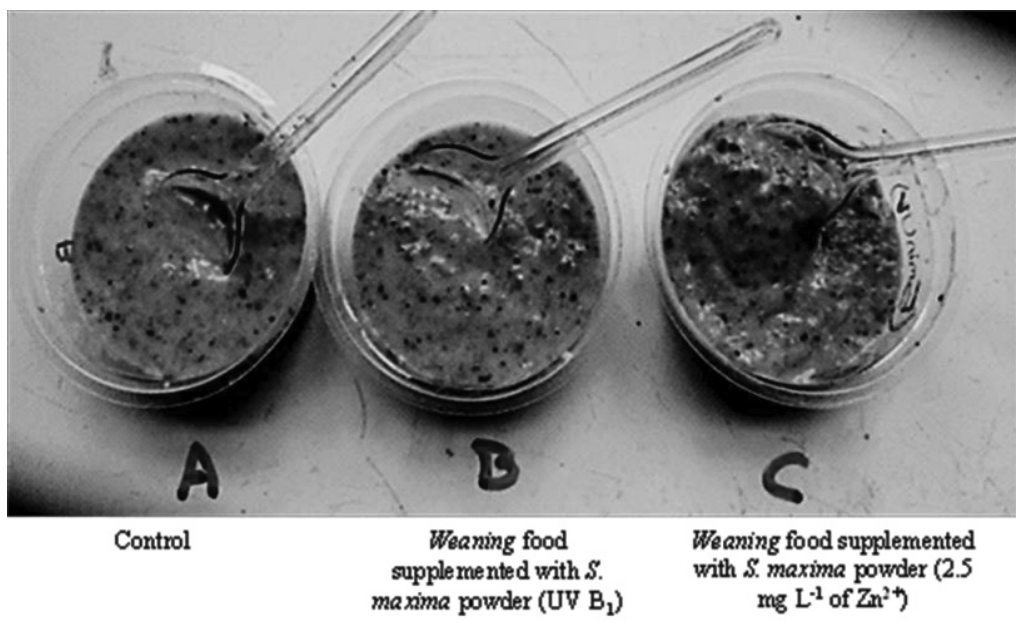

Figure 8. Spirulina-supplemented milk cereal-based weaning food (final product) 
Table 3.

Proximate chemical composition of Spirulina-supplemented milk and cereal-based weaning food

\begin{tabular}{|c|c|c|c|}
\hline Proximate composition & A & B & $\mathbf{C}$ \\
\hline${ }^{*} \mathrm{~L}$ value & $14.23 \pm 1.23^{C}$ & $35.08 \pm 2.35^{a}$ & $22.05 \pm 1.18^{b}$ \\
\hline${ }^{* *}$ a value & $1.29 \pm 0.11^{c}$ & $3.19 \pm 0.15^{\mathrm{a}}$ & $1.34 \pm 0.18^{b}$ \\
\hline${ }^{* * *}$ b value & $1.82 \pm 1.12^{c}$ & $4.53 \pm 1.11^{a}$ & $2.67 \pm 1.19^{b}$ \\
\hline Dry matter $(\mathrm{g} / 100 \mathrm{~g}) \mathrm{FM}$ & $19.15 \pm 2.35^{a}$ & $19.15 \pm 3.24^{a}$ & $18.52 \pm 3.26^{\mathrm{b}}$ \\
\hline Protein(g/100g) DM & $15.34 \pm 1.23^{c}$ & $20.98 \pm 1.65^{a}$ & $18.92 \pm 1.89^{b}$ \\
\hline Fat $(g / 100 g)$ DM & $4.08 \pm 0.23^{a}$ & $3.10 \pm 1.11^{\mathrm{c}}$ & $3.51 \pm 0.78^{b}$ \\
\hline Total ash(g/100g) DM & $1.18 \pm 0.14^{c}$ & $1.31 \pm 012^{a}$ & $1.25 \pm 0.87^{b}$ \\
\hline Fiber $(g / 100 \mathrm{~g}) \mathrm{DM}$ & $0.78 \pm 0.05^{\mathrm{c}}$ & $0.88 \pm 0.06^{b}$ & $1.25 \pm 0.09^{a}$ \\
\hline Carbohydrate $(\mathrm{g} / 100 \mathrm{~g}) \mathrm{DM}$ & $61.73 \pm 2.56^{\mathrm{c}}$ & $70.68 \pm 4.12^{a}$ & $66.98 \pm 3.75^{b}$ \\
\hline Total plate count (CFU/g) DM & $1.03 \times 10^{9}$ & $1.17 \times 10^{9}$ & $1.04 \times 10^{10}$ \\
\hline \multicolumn{4}{|c|}{$\begin{array}{l}\text { A= Without Spirulina powder, } B=\text { Added Spirulina powder }\left(U V-B_{1}\right) \text { and } \mathbf{C}=\text { Added Spirulina powder } \\
\left(2.5 \mathrm{mg} \mathrm{L}^{-1} \mathrm{Zn}^{2+}\right) . \text { Values are means }( \pm S D) . \\
{ }^{*} \mathrm{~L} \text { value=lightness/brightness, } \\
{ }^{* *} \text { a value=greenness/redness, } \\
{ }^{* *} \text { b value=bluishness/yellowishness }\end{array}$} \\
\hline
\end{tabular}

Fermentation has been found to increase pepsin digestibility of millet protein, decrease the concentration of phytic acid and polyphenols with improvement in the availability of minerals (Khetarpaul and Chauhan, 1989, Inyang and Zakari 2008).

\section{Final product formulation}

From the results obtained above, it is evident that pearl millet grains ground for 5 min, cooked with a grain to water ratio of $1: 8$, added with $1 \%$ curd culture and incubated for $12 \mathrm{~h}$ for fermentation and added Spirulina powder at the rate of $1.5 \%$ was found to be most acceptable on the basis of sensory evaluation. The overall schematic representation in the form of flow chart for the development of Spirulina supplemented weaning food is given in Fig. 7.

\section{Proximate composition of developed product}

The results of proximate composition of developed Spirulina-supplemented pearl millet weaning food are given in Table 3 . There were three samples analyzed for proximate composition i.e. weaning food without Spirulina supplementation denoted as sample $A$, weaning food supplemented with Spirulina powder (UV-B $\left.{ }_{1}\right)$ denoted as sample B and with Spirulina powder (2.5 $\mathrm{mg} \mathrm{L^{-1 }}$ of $\mathrm{Zn}^{2+}$ ) denoted as sample C (Fig. 8).

Results showed that the dry matter appeared to be same in the samples $A$ and $B$ whereas sample $C$ exhibited slightly less value. The protein, ash, carbohydrate and crude fibre contents were higher in samples $B$ and $C$ as compared with sample $A$ except fat. Total plate count of the samples $B$ and $C$ was also found to be higher as compared to sample A. The Spirulinasupplemented pearl millet weaning food formulated by the protocol as above was analyzed for its proximate composition as detailed in Table 3.

According to $\mathrm{FAO} / \mathrm{WHO}$ (1982) a minimum protein content of $15 \%$ is required for maximum complementation of amino acids in foods and for growth. In this study, all the three formulations met the protein demands for 1-3 year old children (15$21 \%$, w/w) (Table 3). The ash content indicated the mineral content of the products was higher in the Spirulina-supplemented weaning foods $(1.257-1.316 \%$, w/w) than in the weaning food without Spirulina supplementation $(1.185 \%, \mathrm{w} / \mathrm{w})$. Acceptable ash content of weaning foods, given by the recommendations of the Protein Advisory Group (PAG) (1972) should not exceed $5 \%$. Formulated foods studied in the current study were within this limit as well (Table 3). The fat content of a food sample can affect its shelf life stability, because fat can undergo oxidative deterioration, which leads to rancidification and spoilage. Hence, a food sample with high fat content is more liable to spoilage than one with a lower fat content (Amankwah et al., 2009). The PAG (1972) recommends that the fat content of a weaning food should not exceed $10 \%$ due to oxidative deterioration. 
Thus, the total fat content of formulated product ranging from $3-4 \%$ will not affect its shelf life (Table 3 ). For weaning foods acceptable fibre content should not exceed 5\% according to the PAG (1972) recommendations because high fibre content decreases the digestibility of the particular food for weaning children. The crude fibre content $(0.788-1.258 \% \mathrm{w} / \mathrm{w})$ of the evaluated formulated food was within this acceptable range (Table 3 ). In the present study, $24 \mathrm{~h}$-germinated pearl millet grains was used as the main carbohydrate supplier which helped to maintain the carbohydrate content (66-70\%) over $65 \%$ as in the recommendations made by the PAG (1972).

\section{CONCLUSION}

Pearl millet weaning food is a traditional food of India mainly in rural areas. Great prospects exists in India for value addition and improving health benefits of cereals by combining with milk and milk byproducts and applying advanced technologies for their processing and preservation. Therefore, in order to enhance the flavour and digestibility of traditional pearl millet weaning food, an attempt was made to conduct feasibility studies on the acceptance of fermented pearl millet weaning food (based on milk and cereal weaning foods employing similar technology). It may be concluded that the standardized product consisted of one part of pearl millet ground for 5 min; cooked (1:8), $5 \%$ salt and $0.8 \%$ of cumin powder. Cooked weaning food was mixed with $1 \%$ curd culture, $1.5 \%$ Spirulina powder and incubated for $12 \mathrm{~h}$ (fermentation). The standardized product consisting of this formulation was scored 8.14 points on the 9point hedonic scale as per overall acceptability is concerned. The proximate chemical composition of Spirulina-supplemented milk and cereal-based weaning food was found to be richer as compared to the non-supplemented weaning food. This study was exploratory in nature and sheds light on segments based on panellists' knowledge regarding the sensory attributes of milk cereal-based probiotic food of Spirulina, but further in-depth research is required on its shelf life determination, development of such product at industrial scale, consumers' preference and purchasing behaviour and attitudes towards the product. This will enable the future use of microbes and microbial fermentations for a widening area in food technology and in functional and clinical food areas.

\section{ACKNOWLEDGEMENTS}

We are thankful to Dr. Latha Sabhiki, senior scientist, Dairy Division, National Dairy Research Institute, Karnal, Haryana for providing the culture of NCDC167.

\section{REFERENCES}

1. Abbey, B.W., Berezi, P.E. (1988). Influence of processing on the digestibility of African yam bean flour. Nutrition Reports International Journal, 32, 819-827.

2. Akubor, P.I., Obiegbuna, J.E. (1999). Certain chemical and functional properties of ungerminated millet flour. Journal of Food Science and Technology, 36, 241-243.

3. Amankwah, E.A., Barimah, J., Nuamah, A.K.M., Oldham, J.H., Nnaji, C.O., Knust, P. (2009). Formulation of weaning food from fermented maize, rice, soybean and fishmeal. Pakistan Journal of Nutrition, 8 (11), 1747-1752.

4. AOAC (1984). Official Methods of Analysis of AOAC International, 16th Ed., Association of Official Analytical Chemist, Maryland, USA.

5. Batista, A.P., Gouveia, L., Bandarra, N.M., Franco, J.M., Raymundo, A. (2013). Comparison of micro-algal biomass profiles as novel functional ingredient for food products. Algal Research, 2, 164-173.

6. Bhowmik, D., Dubey, J., Mehra, S. (2009). Probiotic efficiency of Spirulina platensis stimulating growth of lactic acid bacteria. World Journal of Dairy Food Science, 4, 160-163.

7. Charalampopoulos, D., Wang, R., Pandiella, S.S., Webb, C. (2002). Application of cereals and cereal components in functional foods: a review. International Journal of Food Microbiology, 79 (1-2), 131-141.

8. Ciferri, O. (1983). Spirulina, the edible microorganism. Microbiological Reviews, 47, 551-578.

9. Egounlety, M. (2002). Production of legume-fortified weaning foods. Food Research International, 35 (2), 233-237.

10. Ejeta, G., Hassen, M.M., Mertz, E.T. (1987). In vitro digestibility and amino acid composition of pearl millet (Pennisetum typhoides) and other cereals. Proceedings of the Natural Academy Science, 84, 6016-6019.

11. El Hag, M.E., Abdullahi, H.E., Nabila, E.Y. (2002). Effect of fermentation and dehulling on starch, total polyphenols, phytic acid content and in vitro protein digestibility of pearl millet. Food Chemistry, 77, 193- 196.

12. Finamore, A., Palmery, M., Bensehaila, S., Pe- 
luso, I. (2017). Antioxidant, immunomo-dulating, and microbial-modulating activities of the sustainable and ecofriendly Spirulina. Oxidative Medicine and Cellular Longevity, 14, 1-14.

13. (FAO) Food and Agriculture Organization of the United Nations (2012). The state of food insecurity in the world. FAO, Viale delle Terme di Caracalla, 00153 Rome, Italy.

14. (FAO) Food and Agriculture Organization of the United Nations / (WHO) World Health Organization (1982). Codex Standard for Foods for Special Dietary Uses Including Foods for Infants and Children and Related Code of Hygienic Practice, $1^{\text {st }}$ ed., Codex Alimentarius, Rome, Italy.

15. Hassen, A.B., Ahmed, I.A.M., Osman, N.M., Eltayeb, M.M., Osman, G.A., Babiker, E.E. (2006). Effect of processing treatments followed by fermentation on protein content and digestibility of pearl millet (Pennisetum typhoideum) cultivars. Pakistan Journal of Nutrition, 5 (1), 8689.

16. Hulse, J.H., Laing, E.M., Pearson, O.E. (1980). Sorghum and the millets: their composition and nutritive value. Academic Press, London.

17. Inyang, C.U., Zakari, U.M. (2008). Effect of germination and fermentation of pearl millet on proximate, chemical and sensory properties of instant "Fura"- a Nigerian cereal food. Pakistan Journal of Nutrition, 7 (1), 9-12.

18. Karkos, P.D., Leong, S.C., Karkos, C.D., Sivaji, N., Assimakopoulos, D.A. (2011). Spirulina in clinical practice: evidence-based human applications. Journal of Evidence-Based Complementary \& Alternative Medicine, Article ID 531053, 4 pages. doi:10.1093/ecam/nen058.

19. Kamenidou, I., Aggelopoulos, S., Batzios, A.C. (2011). Natural medical attributes and benefits of Spirulina: segmentation based on consumers' knowledge. Journal of Medicinal Plants Research, 5 (14), 3192-3199.

20. Khetarpaul, N., Chauhan, B.M. (1989). Effect of germination and fermentation on $\mathrm{HCl}$-extractability of minerals of pearl millet. International Journal of Food Science and Technology, 24, 324-329.

21. Kumar, J., Parihar, P., Singh, R., Singh, V.P., Prasad, S.M. (2016). UV-B induces biomass production and nonenzymatic antioxidant compounds in three cyanobacteria. Journal of Applied Phycology, 28, 131-140.

22. Marles, R.J., Barrett, M.L., Barnes, J. (2011). United States pharmacopeia safety evaluation of Spirulina. Critical Reviews Food Science Nutrition, 51 (7), 593-604.

23. Mishra, P., Singh, V.P., Prasad, S.M. (2014). Spirulina and its nutritional importance: A possible approach for development of functional food. Biochemistry and Pharmacology, 3 (6), 12.

24. Mishra, P., Prasad, S.M. (2015). Evaluation of anticandidal activities of Spirulina metabolite against Candida albicans. International Journal of Pharmaceutical Science and Research, 6 (3), 1241-1247.
25. Munasinghe, M.A.D.D., Silva, K.F.S.T., Rasika, D.M.D., Jayarathne, M.P.K., Sarananda, K.H. (2013). Formulation and sensory evaluation of yoghurt-based weaning foods manufactured from mung bean, soybean and brown rice. International Journal of Scientific Research Publications, 3 (4), 1-9.

26. Narasimha, H.V., Malleshi, N.G. (2003). Specialty foods based on millets and pulses for health and medical benefits. $5^{\text {th }}$ International Food Convention, Mysore, India, Book of $A b$ stracts.

27. National Research Council (1996). Pearl Millet. In Lost Crops of Africa, Volume1: Grains. National Academic Press, Washington, D.C., pp. 77-92.

28. Ojokoh, A.O., Fayemi, O.E., Ocloo, F.C.K., Nowkolo, F.I. (2015). Effect of fermentation on proximate composition, physicochemical and microbial characteristics of pearl millet (Pennisetum glaucum (L.) R. Br.) and acha (Digitaria exilis (Kippist) Stapf) flour blends. Journal of Agricultural Biotechnology and Sustainable Development, 7 (1), 1-8.

29. Patel S., Goyal A. (2013) Current and prospective insights on food and pharmaceutical applications of Spirulina. Current Trends in Biotechnology and Pharmacy, 7 (2), 696-707.

30. PFA (2008). Prevention of Food Adulteration Act (1954), Professional Food Publishers, New Delhi.

31. (PAG) Protein Advisory Group (1972). Guidelines of Protein Rich Mixture for Use in Weaning Foods. Protein Advisory Group, New York.

32. Pulz, O., Gross, W. (2004). Valuable products from biotechnology of microalgae. Applied Microbiology and Biotechnology, 65, 635-648.

33. Ranganna, S. (2005). Handbook of Analysis and Quality Control for Fruits and Vegetable products, $2^{\text {nd }}$ ed., Tata Mc.Graw Hill Book Co., New Delhi.

34. Rodrigues, C.S., Villela, H.D.M., Martins, A.P., Marques, L.G., Colepicolo, P., Tonon, A.P. (2015). Microalgae for economic applications: advantages and perspectives for bioethanol. Journal of Experimental Botany, 66 (14), 40974108.

35. Sabikhi, L. (2007). Designer milk. Advances in Food and Nutrition Research, 53, 161-98.

36. Sajilata, M.G., Singhal, R.S., Kamat, M.Y. (2008). Fractionation of lipids and purification of g-linolenic acid (GLA) from Spirulina platensis. Food Chemistry, 109, 580-586.

37. Sanni, A.I., Onilude, A.A., Ibidapo, O.T. (1999). Biochemical composition of infant weaning food fabricated from fermented blends of cereal and soybean. Food Chemistry, 65 (1), 35-39.

38. Sarkar, S. (2011). Probiotics, prebiotics and synbiotics for infant feeding - a review. Journal of Microbial \& Biochemical Technology S1:004. doi:10.4172/1948- 5948.S1-004.

39. Sofowora, A. (1993). Medicinal Plants and Traditional Medicine in Africa, Spectrum Books Ltd. Ibadan Nigeria, pp. 191-289.

40. Stone, H., Sidel, H., Oliver, S., Woodesey, A., Singlehon, R.C. (1974). Sensory evaluation by 
quantitative descriptive analysis. Food Technology, 28 (1), 24-26.

41. Trease, G.E., Evans, W.C. (2002). Pharmacology, $15^{\text {th }}$ ed., Saunders Publishers, London, pp. 42- 44, 221-229, 246-249, 303-306, 331-332, 391-393.

42. Yang, Y., Park, Y., Cassada, D.A., Snow, D.D., Rogers, D.G., Lee, J. (2011). In vitro and in vivo safety assessment of edible blue-green algae,
Nostoc commune var. Spharoides kutzing and Spirulina platensis. Food and Chemical Toxicology, 49, 1560-1564.

43. Zarrouk, C. (1966). Contribution à l'étuded'une cyanophycée. Influence de divers' facteurs physiques et chimiques sur la croissance et la photosynthèse de Spirulina maxima Geitler. PhD Thesis, Université de Paris, Paris.

\title{
PАЗВОЈ СИМБИОТИЧКЕ ЧВРСТЕ ХРАНЕ ЗА ОДОЈЧАД И МАЛУ ДЕЦУ ОБОГАЋЕНЕ СПИРУЛИНОМ УЗГОЈЕНОМ ПОД КОНТРОЛИСАНИМ УСЛОВИМА БЛАГОГ СТРЕСА
}

\author{
Pragya Mishra* ${ }^{*}$, Sheo Mohan Prasad ${ }^{2}$, Neelam Yadav ${ }^{1}$ \\ ${ }^{1}$ Универзитет у Алахабаду, Центар за прехрамбену технологију, Алахабад, Индија \\ ${ }^{2}$ Универзитет у Алахабаду, Департман за ботанику, Лабораторија за физиологију биљака и \\ биохемију, Алахабад, Индија
}

Сажетак: У циљу ублажавања неухрањености код деце а у складу са повећаном свешћу потрошача о здравственом аспекту исхране, развијене су формулације функционалне чврсте хране за одојчад и малу децу користећи природне ресурсе попут микроалги, нарочито цијанобактерија. У научној и стручној литератури досада нису објављени методи од научног и техничког значаја за развој чвсте хране за одојчад на бази проса која је обогаћена спирулином (Spirulina maxima). У овом раду је процењивана изводљивост фрормулисања овакве хране на бази оцене сензорских својстава. Извршено је испитивање физичко-хемијских својстава праха од спирулине која је гајена у оптималним лабораторијскм условима. Стандардизован производ се састојао од једног дела млевеног проса куваног у 8 делова воде, 5\% соли и 0,8\% кумина у праху. Тако припремљеној храни додато је $1 \%$ бактеријске културе за сирење и 1,5\% спирулине у праху. Након тога је спроведена ферментација у току 12 сати. Стандардизован производ ове формулације је добио следеће оцене након сензорске евалуације на хедонској скали од 9 бодова: 8,13 бодова за боју и изглед, 7,93 бодова за укус, 7,88 бодова за конзистенцију, 7,94 осећај у устима, 7,30 киселост и 8,14 за укупну прихватљивост.

Кључне речи: спирулина, чвста храна за одојчад, сензорска својства, фрерментација, хедонска скала

Received: 25 April 2017

Accepted: 3 August 2017 